\title{
Cholesterol and Bile Acids Regulate Cholesterol $7 \alpha$-Hydroxylase Expression at the Transcriptional Level in Culture and in Transgenic Mice
}

\author{
MARIA I. RAMIREZ, DENISE KARAOGLU, DIEGO HARO, † CARMEN BARILLAS, \\ ROYA BASHIRZADEH, AND GREGORIO GIL* \\ Department of Biochemistry and Molecular Biology, University of Massachusetts \\ Medical School, Worcester, Massachusetts 01655
}

Received 10 November 1993/Returned for modification 14 January 1994/Accepted 24 January 1994

\begin{abstract}
Cholesterol $7 \alpha$-hydroxylase (7 $\alpha$-hydroxylase) is the rate-limiting enzyme in bile acid biosynthesis. It is subject to a feedback control, whereby high levels of bile acids suppress its activity, and cholesterol exerts a positive control. It has been suggested that posttranscriptional control plays a major part in that regulation. We have studied the mechanisms by which cholesterol and bile acids regulate expression of the 7 $\alpha$-hydroxylase gene and found it to be solely at the transcriptional level by using two different approaches. First, using a tissue culture system, we localized a liver-specific enhancer located $7 \mathrm{~kb}$ upstream of the transcriptional initiation site. We also showed that low-density lipoprotein mediates transcriptional activation of chimeric genes, containing either the $7 \alpha$-hydroxylase or the albumin enhancer in front of the $7 \alpha$-hydroxylase proximal promoter, to the same extent as the in vivo cholesterol-mediated regulation of $7 \alpha$-hydroxylase mRNA. In a second approach, using transgenic mice, we have found that expression of an albumin enhancer-7 $\alpha$ hydroxylase-lacZ fusion gene is restricted to the liver and is regulated by cholesterol and bile acids in a manner quantitatively similar to that of the endogenous gene. We also found, that a liver-specific enhancer is necessary for expression of the rat $7 \alpha$-hydroxylase gene, in agreement with the tissue culture experiments. Together, these results demonstrate that cholesterol and bile acids regulate the expression of the $7 \alpha$-hydroxylase gene solely at the transcriptional level.
\end{abstract}

Cholesterol homeostasis is maintained through the regulation of three metabolic pathways. Two pathways function in the supply of cholesterol to cells. These include an endogenous biosynthetic pathway in which cholesterol is synthesized from acetate precursors and an exogenous pathway in which the low-density lipoprotein (LDL) receptor internalizes cholesterol-carrying lipoprotein particles from the blood (20). A third pathway functions in the catabolism of cholesterol and involves its conversion to bile acids. Improper regulation of this pathway has pathological implications because the major pathway for the catabolism and excretion of cholesterol in mammals is the formation of bile acids. The rate of elimination of cholesterol is a critical factor in diseases such as atherosclerosis, gallstone disease, and some lipid storage diseases $(5,11,13)$. The initial and rate-limiting step in this pathway is the hydroxylation of cholesterol at position 7 and is catalyzed by the enzyme cholesterol $7 \alpha$-hydroxylase ( $7 \alpha$-hydroxylase) (cholesterol $7 \alpha$-monooxygenase; EC 1.14.13.17), a microsomal cytochrome P450 (35). This enzyme is subject to a feedback control, whereby high levels of bile acids returning to the liver via the enterohepatic circulation suppress its activity. Cholesterol, the substrate of the enzyme, exerts a positive control.

The rat and human $7 \alpha$-hydroxylase cDNAs have been isolated by several groups $(7,26,30,37,38)$. The availability of these molecular probes has facilitated studies directed towards

\footnotetext{
* Corresponding author. Mailing address: Department of Biochemistry and Molecular Biology, University of Massachusetts Medical School, 55 Lake Avenue North, Worcester, MA 01655. Phone: (508) 856-6138. Fax: (508) 856-2391.

$\uparrow$ Present address: Department of Biochemistry and Molecular Biology, School of Pharmacy, University of Barcelona, 08028 Barcelona, Spain.
}

understanding the molecular mechanisms that regulate bile acid synthesis. For example, Jelinek et al. have shown that the $7 \alpha$-hydroxylase gene is expressed only in liver (26), as expected, since bile acids are synthesized only in that organ (35). Also, the activity of $7 \alpha$-hydroxylase exhibits a circadian rhythm in rats, with a maximum at midnight and a minimum during the daytime (35). This diurnal variation of enzyme activity is due to changes in the protein and mRNA levels (39) and appears to be due, at least in part, to variable levels of glucocorticoids (32).

Specific dietary manipulations have been shown to alter $7 \alpha$-hydroxylase protein levels, enzyme activity, and mRNA levels. Cholestyramine, a resin that binds bile acids, thus reducing their levels in the liver, and cholesterol feeding of rats effectively up-regulates $7 \alpha$-hydroxylase protein levels and enzyme activity by increasing the amount of $7 \alpha$-hydroxylase mRNA about twofold $(26,30,39,53)$. In addition, $7 \alpha-$ hydroxylase mRNA and protein levels decrease (5- to 10-fold) when rats are fed bile acids (26).

Different approaches have been used to study the molecular mechanism(s) involved in the bile acid- and cholesterol-mediated regulation of the $7 \alpha$-hydroxylase gene. It has been proposed that transcriptional regulation plays a role by analogy with other systems involved in cholesterol homeostasis $(26,33$, $46,52)$. Studies in tissue culture systems have been difficult because of the lack of appropriate cell lines with which transcriptional regulation could be studied. Recently, chimeric genes containing fragments of the 5 '-flanking region of the human $7 \alpha$-hydroxylase gene have been expressed in HepG2 cells, but it is not known whether they are regulated by cholesterol and/or bile acids (33). Bile acid-mediated regulation of $7 \alpha$-hydroxylase mRNA and transcription has been shown in isolated primary rat hepatocytes $(24,52)$, although 
the extent of regulation (2-fold) differs from the regulation of mRNA levels in the entire animal (5- to 10 -fold $)(26,53)$. It has been suggested that posttranscriptional control plays a major part in that regulation as shown by nuclear run-on assays (52) and by the discrepancy between the bile acid-mediated regulation of $7 \alpha$-hydroxylase mRNA in hepatocytes in culture (ninefold) compared with the twofold decrease in transcription as quantified by run-on or by the suppression of a chloramphenicol acetyltransferase (CAT) activity directed by promoter constructs containing up to $3.6 \mathrm{~kb}$ of $7 \alpha$-hydroxylase upstream sequences.

Two methods are currently available to test for regulated expression of the transcription of cloned genes. One approach is to introduce a purified gene into cells in culture by transfection. Regulation is measured by the differential expression of a gene in an appropriate cell line upon addition of the effector. Major advantages of this method are the relative ease in testing multiple genes or altered gene constructs and the speed of the assay. It is impractical, however, when cell-specific functions ought to be studied, since cells in culture tend to express all transfected eukaryotic genes at a low basal level regardless of cell specificity. Similarly, conditions such as cholesterol homeostasis require whole animal models to study the complex interaction of whole organ systems. The other approach of choice is to introduce cloned genes into all cells of an animal by microinjection into fertilized eggs to create transgenic animals (41). A major advantage of this method is the ability to assay for expression in many tissues of an animal. It also provides a more physiological system for studying tissue-specific and developmentally regulated genetic elements (42). The limitation of transgenic technologies is the length of time required for the production and generation of several lines of transgenic animals containing a single gene construct.

In the present study, we used both approaches to investigate the regulation of the expression of the $7 \alpha$-hydroxylase gene. First, we used a conditionally transformed hepatocyte cell line, $\mathrm{H} 2.35$ (56), to transfect chimeric genes containing different portions of the $5^{\prime}$-flanking region of the rat $7 \alpha$-hydroxylase gene. This system allowed us to localize a liver-specific enhancer located $7 \mathrm{~kb}$ upstream of the transcriptional initiation site. We have also shown that LDL mediates transcriptional activation of chimeric genes containing either the $7 \alpha$-hydroxylase or the albumin enhancer in front of the $7 \alpha$-hydroxylase promoter in differentiated liver cells, to the same extent as the in vivo cholesterol-mediated regulation of $7 \alpha$-hydroxylase mRNA. However, bile acids only partially (twofold) regulated rat $7 \alpha$-hydroxylase promoter activity in that tissue culture system. Thus, we used transgenic mice to study that regulation, and we showed that mice harboring a chimeric gene carrying the $7 \alpha$-hydroxylase 5 '-flanking region with the albumin enhancer expressed the reporter gene whereas a fusion gene containing the same $7 \alpha$-hydroxylase proximal promoter but without enhancer did not show expression. This analysis supported our tissue culture experiments which indicate that either the $7 \alpha$-hydroxylase enhancer or the albumin enhancer is necessary for transcription of the $7 \alpha$-hydroxylase promoter (see Fig. 1, 2, and 6). More importantly, expression of the transgene is regulated by cholesterol and bile acids in a manner similar to the expression of the endogenous gene. These results demonstrate that cholesterol and bile acids regulate the expression of the $7 \alpha$-hydroxylase gene solely at the transcriptional level. The systems presented in this article provide experimental approaches to study cholesterol- and bile acidmediated regulation of $7 \alpha$-hydroxylase transcription.

\section{MATERIALS AND METHODS}

Materials. ${ }^{32} \mathrm{P}$-labeled nucleotides, ${ }^{35} \mathrm{~S}$-dATP and $\left[{ }^{14} \mathrm{C}\right]$ chloramphenicol were purchased from Du Pont New England Nuclear, Boston, Mass. Restriction enzymes and other enzymes used in DNA cloning and DNA sequencing were obtained from commercial sources and used according to recommendations of the manufacturer. $\lambda$ GEM- 11 and pCAT (a promoterless plasmid containing the coding region of the bacterial CAT gene and the simian virus 40 [SV40] $t$ intron and polyadenylation signals) (45) were obtained from Promega, Madison, Wis. Oligonucleotides were synthesized by the phosphoramidite method on an Applied Biosystems model 380A DNA synthesizer. G418 sulfate (Geneticin) was purchased from GIBCO Laboratories. pSV3-neo, a plasmid that confers resistance to the neomycin (Neo) analog G418, was obtained from Bethesda Research Laboratories. Mouse chow was obtained from Agway Inc. (Syracuse, N.Y.). Cholesterol was purchased from ICN Biochemicals (Cleveland, Ohio). Colestipol (Colestid) was purchased from The Upjohn Co. (Kalamazoo, Mich.); cholic acid and chenodeoxycholic acid were obtained from Sigma.

General methods. Restriction enzyme digestions, agarose gel electrophoresis, and DNA and RNA blotting and hybridization were carried out by standard procedures as described by Sambrook et al. (48). DNA probes were ${ }^{32} \mathrm{P}$ labeled by the method of Church and Gilbert (9). DNA sequencing was done by the dideoxy chain termination method of Sanger et al. (49) with either the M13 universal sequencing primer or specific oligonucleotides, after subcloning into bacteriophage M13 vectors (48). In certain GC-rich regions, $20 \%$ formamide was used in the sequencing gels (12). Both strands were sequenced at least once. Human LDL and lipoprotein-deficient fetal calf serum were prepared by ultracentrifugation (18). Protein content was measured by the method of Bradford (2).

Cloning of the rat $7 \alpha$-hydroxylase gene. Rat liver DNA was prepared as described elsewhere (48). After partial Sau3AI digestion, fragments ranging in size between 15 and $25 \mathrm{~kb}$ were purified and ligated to the Bam $\mathrm{HI}$ arms of the cloning vector $\lambda$ GEM-11. After in vitro packaging of the recombinant molecules into infectious phage particles, clones were screened for inserts containing $7 \alpha$-hydroxylase sequences by in situ hybridization (48) using as a probe an oligonucleotide complementary to nucleotides +86 to +125 , which corresponds to the beginning of the coding region of the published rat $7 \alpha$ hydroxylase cDNA sequence (37). Two clones, $\lambda R 7 \alpha-1$ and $\lambda R 7 \alpha-2$, were identified out of $3 \times 10^{5}$ recombinants. For more detailed analysis of $\lambda$ clones, subgenomic fragments were generated by digestion with EcoRI, BamHI, and PstI and subcloned into plasmid vectors. The transcriptional initiation site was determined by primer extension and $\mathbf{S} 1$ nuclease analysis and coincided, essentially, with the position described by Jelinek et al. (27).

Plasmid constructions. Plasmid pR $7 \alpha \mathrm{CAT}-1$ was constructed by insertion of a 4-kb PstI fragment, excised from $\lambda R 7 \alpha-1$, which spans from $1.6 \mathrm{~kb}$ upstream of the transcriptional initiation site to the second intron in the $7 \alpha$-hydroxylase gene. To delete the first two exons from this construct, we introduced a SalI site at position +59 (Fig. 1) by PCR techniques (47) and ligated it to the SalI site in the polylinker of pCAT, upstream of the CAT gene, to generate pR7 $\alpha$ CAT-3. pR7 $\alpha$ CAT-9 and pR7 $\alpha$ CAT- 8 were made by inserting the $X b a I-P s t I$ fragments $(-7455$ to -1671 and -6265 to -1671 , respectively) into the PstI site of pR7 $\alpha$ CAT-3. pR7 $\alpha$ CAT-10 was created by deletion of the $X b a I-S p h I$ fragment in pR7 $\alpha$ CAT- 8 and recircularization. pR7 $\alpha$ CAT-5 was made 


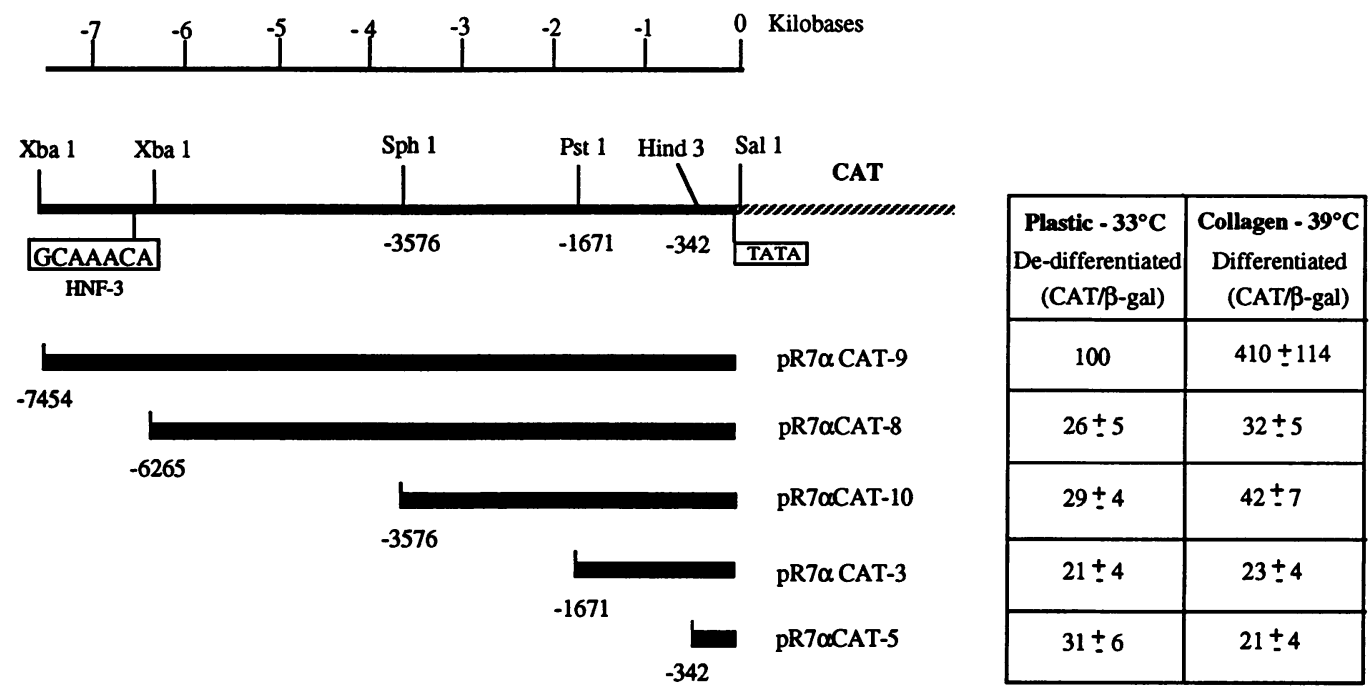

FIG. 1. Promoter activity of $5^{\prime}$ deletion mutants of the rat $7 \alpha$-hydroxylase promoter in $\mathrm{H} 2.35$ cells. The DNA fragment (thin solid bar) from the $5^{\prime}$-flanking region of the rat $7 \alpha$-hydroxylase gene is shown with the restriction sites used for plasmid constructoin (see Materials and Methods). The CAT coding sequence is denoted by the hatched bar. The putative TATA box and a potential TGT3-HNF-3 site are indicated. A scheme of the different chimeric genes used is shown. H2.35 cells were stably transfected with the indicated plasmid as explained in Materials and Methods. After selection of G418 resistant colonies, cells were cultured under differentiating or nondifferentiating conditions as described in Materials and Methods. Relative transcription was determined by measuring CAT activity with amounts of extracts that contained the same amount of $\beta$-galactosidase ( $\beta$-gal) activity. The data are expressed as percentages of the activity produced by the construct containing the longest promoter fragment, pR7 $\alpha$-CAT-9, under dedifferentiating conditions and represent the averages of seven experiments with two different transfections \pm standard errors of the mean.

from $\mathrm{pR} 7 \alpha \mathrm{CAT}-3$ by HindIII digestion and recircularization. p7 $\alpha$ E-R $7 \alpha$ CAT-5 was made by blunt-end ligation of the $X b a \mathrm{I}-$ $X b a I$ fragment $(-7454$ to -6265 from the $7 \alpha$-hydroxylase transcription initiation site) into the HindIII site of pR7 $\alpha$ CAT-5. pAE-R7 $\alpha$ CAT-5 was prepared by blunt-end ligation of the NheI-BamHI fragment $(-10400$ to -8500 from the mouse albumin gene [43]) excised from pAN/T2-NB' (a plasmid that contains the mouse albumin enhancer and promoter, kindly provided by $\mathrm{K}$. S. Zaret, Brown University) into the HindIII site of pR7 $\alpha$ CAT-5. pGal, a promoterless plasmid containing the bacterial lac $Z$ gene, was constructed by replacing the bacterial CAT coding region from pCAT by the lacZ gene obtained by DraI digestion of pNK 1915 (a gift from P. Dobner, University of Massachusetts Medical School). pR7 $\alpha$ Gal-3 was made by ligation of a 4.1-kb BamHI-SalI fragment containing the lacZ gene and the SV40 $t$ intron and poly(A) addition site from pGal to the 4.4-kb BamHI-SalI backbone from pR7 $\alpha$ CAT-3. pAE-7 $\alpha$ Gal-3 was prepared by blunt-end ligation of the NheI-BamHI fragment into the Pst I site of the plasmid $\mathrm{pR} 7 \alpha \mathrm{Gal}-3$. Plasmid DNA was purified by two $\mathrm{CsCl}$ gradients, and the integrity of the DNA was verified by sequencing when necessary.

Cell culture and transfection experiments. $\mathrm{H} 2.35$ cells (56) (a temperature-sensitive, SV40-transformed mouse hepatocyte cell line kindly provided by $\mathrm{K}$. S. Zaret) were cultured as described by Zaret et al. (56). Briefly, cells were maintained in basal medium (Dulbelcco's modified eagle medium supplemented with $4 \%$ fetal calf serum, $0.2 \mu \mathrm{M}$ dexamethasone, and antibiotics) at $33^{\circ} \mathrm{C}$ in a humidified atmosphere of $5 \% \mathrm{CO}_{2}$. Cells were cotransfected by the calcium phosphate method as modified by Chen and Okayama (6), using $15 \mu \mathrm{g}$ of the test plasmid and $1 \mu \mathrm{g}$ of pSV3-neo. To normalize for efficiency of transfection, a reference plasmid (pSV-gal; $4 \mu \mathrm{g}$ ) containing the bacterial lacZ gene under the control of the SV40 early promoter was cotransfected with the test plasmid. Selection with G418 $(1 \mathrm{mg} / \mathrm{ml})$ was maintained for 2 weeks. Resistant colonies were pooled (150 to 300 colonies per transfection) and expanded in mass culture in the presence of $1 \mathrm{mg}$ of G418 per ml.

For each experiment, 100 -mm-diameter plastic dishes were seeded on day 0 at $10^{6}$ cells per dish in $8 \mathrm{ml}$ of basal medium and incubated at the permissive temperature for $\mathrm{SV} 40,33^{\circ} \mathrm{C}$ (dedifferentiating conditions). For differentiating conditions, $100-\mathrm{mm}$-diameter dishes containing $4 \mathrm{ml}$ of a $1.35-\mathrm{mg} / \mathrm{ml}$ gel of rat type I collagen prepared exactly as described by Zaret et al. (56) were seeded with $2 \times 10^{6}$ cells per dish in $8 \mathrm{ml}$ of basal medium supplemented with $10 \%$ fetal calf serum. After the cells on collagen were cultured at the nonpermissive temperature $\left(39^{\circ} \mathrm{C}\right)$ for 3 to $5 \mathrm{~h}$, the medium was replaced by serum-free medium (56) and maintained at $39^{\circ} \mathrm{C}$. On day 2 , cells were refed with either basal medium or serum-free medium and harvested by scraping (plastic dishes) or by a brief collagenase digestion (collagen plates) on day 3. Cells were lysed by three cycles of freeze-thawing, and $\beta$-galactosidase activity was determined as described by Sambrook et al. (48) with $o$-nitrophenyl- $\beta$-D-galactopyranoside as a substrate. One unit of $\beta$-galactosidase activity is defined as the amount of enzyme that transforms $1 \mu \mathrm{mol}$ of substrate per min at $37^{\circ} \mathrm{C}$. CAT activities were measured by the method of Gorman et al. (21), after the cell extracts were incubated at $65^{\circ} \mathrm{C}$ for $5 \mathrm{~min}$. One unit of CAT activity is defined as the amount of enzyme which transforms $1 \mathrm{nmol}$ of chloramphenicol into its acetylated products per min at $37^{\circ} \mathrm{C}$. All assays were linear regarding time of incubation and concentration of protein.

DNA preparation for microinjection and generation of transgenic mice. For microinjection, the $\mathrm{pR} 7 \alpha \mathrm{CAT}-3$ fusion gene (see Fig. 5) was prepared by PstI-BamHI digestion of pR7 $\alpha$ CAT-3 $(3.4 \mathrm{~kb})$. The AE-7 $\alpha \mathrm{Gal}-3$ fusion gene $(7.8 \mathrm{~kb})$ (see Fig. 5) was prepared by Bam HI complete digestion and $S p h I$ partial digestion of pAE-7 $\alpha \mathrm{Gal}-3$. DNA fragments were 
isolated by agarose gel electrophoresis and electroelution and further purified with Elutip minicolumns (Schleicher \& Schuell). Linearized DNA was dissolved in $5 \mathrm{mM}$ Tris $(\mathrm{pH}$ 7.4)-0.1 mM EDTA at a final concentration of $1 \mu \mathrm{g} / \mathrm{ml}$. Two to five picoliters was microinjected into the male pronucleus of fertilized B6SJLF1/J embryos (Jackson Laboratories, Bar Harbor, Maine) by standard techniques and transferred into the oviducts of pseudopregnant CD1 foster mothers (23). Founder males were mated to female wild-type C57BL/6 mice.

DNA analysis and estimation of gene copy number. To identify transgenic founder mice, genomic DNA was isolated from the tails of 4- to 5-week-old pups, digested with EcoRI (for R7 $\alpha$ CAT-3) or with AvaII (for AE-R $7 \alpha \mathrm{Gal}-3$ ), and subjected to Southern blot analysis. Hybridization was done with a ${ }^{32}$ P-labeled single-stranded M13 probe (9) prepared from the coding region of the CAT gene or from a 419-bp fragment of the $7 \alpha$-hydroxylase-lac $Z$ fusion gene $(-267$ to +152$)$. The number of copies of inserted DNA per genome was estimated by using a calibration curve of pR7 $\alpha$ CAT-3 or pAE- $7 \alpha \mathrm{Gal}-3$ DNA, processed under the same conditions. Further generations of transgenic mice were detected by PCR techniques using blood samples (29) to screen a large number of offspring. A 465-bp fragment of the $5^{\prime}$ region of the lac $Z$ gene was amplified (47).

Feeding of mice. Transgenic mice were kept under a 12-h light/12-h dark cycle. Male and female mice, 6 to 8 weeks old, were fed as follows: (i) regular chow diet (normal diet), (ii) normal diet supplemented with $2 \%$ (wt/wt) cholesterol for 14 days, (iii) normal diet supplemented with $5 \%$ (wt/wt) colestipol for 5 days, (iv) normal diet supplemented with $0.5 \%$ (wt/wt) cholic acid for 5 days, or (v) normal diet supplemented with $0.5 \%(\mathrm{wt} / \mathrm{wt})$ chenodeoxycholic acid for 5 days. Animals were killed between the 6th and 8th of the dark period.

Preparation of tissue extracts and assay of $\beta$-galactosidase activity. Mouse tissues $(0.5 \mathrm{~g})$ were homogenized in a Dounce homogenizer on ice, with $5 \mathrm{ml}$ of $40 \mathrm{mM}$ Tris- $\mathrm{HCl}$ (pH 7.4)-1 $\mathrm{mM}$ EDTA-500 mM sucrose- $150 \mathrm{mM} \mathrm{NaCl}-10 \mathrm{mM}$ dithiothreitol. The lysates were cleared by centrifugation at $10,000 \times$ $g$ for $30 \mathrm{~min}$ at $4^{\circ} \mathrm{C}$. The soluble fraction was purified by ultracentrifugation at $100,000 \times g$ for $90 \mathrm{~min}$ at $4^{\circ} \mathrm{C}$ and used to quantify $\beta$-galactosidase or CAT activity.

RNA purification and analysis. Total cellular RNA was isolated from tissue-cultured cells by guanidinium thiocyanate extraction followed by centrifugation through a cesium chloride cushion (8). Primer extension analysis of Neo mRNA was performed with $15 \mathrm{fmol}$ of a 40-nucleotide synthetic DNA primer complementary to nucleotides +261 to +300 of $\mathrm{Neo}$ RNA (1). To initiate primer extension, $100 \mathrm{U}$ of Moloney murine leukemia virus reverse transcriptase was added to the mixture and incubated for $1 \mathrm{~h}$ at $37^{\circ} \mathrm{C}$ in the presence of deoxynucleotides as described elsewhere (15). S1 nuclease analysis of the $5^{\prime}$ end of the $7 \alpha$-hydroxylase-CAT mRNA was performed essentially as described elsewhere (15), except that the annealing temperature was $44^{\circ} \mathrm{C}$, by using a single-stranded probe that spans from position -39 in the $7 \alpha$-hydroxylase 5 '-flanking region to the EcoRI site within the CAT coding region.

Total RNA was purified from mouse liver by guanidinium thiocyanate homogenization followed by centrifugation through a cesium chloride cushion (8). Equal amounts of the individual RNA samples (five to seven per group) were pooled. Poly $(\mathrm{A})^{+}$RNA was isolated from those pools by using a Mini Ribo Sep Ultra mRNA isolation kit (Collaborative Biomedical Products, Bedford, Mass.). RNA slot blotting and hybridization were carried out by standard procedures (48). Three different M13 single-stranded probes, prepared as described by
Church and Gilbert (9), were used. The $\beta$-galactosidase probe was a 419 -bp fragment $(-267$ to +152$)$ from the $7 \alpha$-hydroxylase-lac $Z$ fusion gene; the $7 \alpha$-hydroxylase probe contained a $1.1-\mathrm{kb}$ Bam HI fragment from the $5^{\prime}$ end of the rat $7 \alpha-$ hydroxylase cDNA. As a control, we used a hamster albumin cDNA probe (16). $7 \alpha$-Hydroxylase and albumin hybridizations were done in $35 \%$ (vol/vol) formamide solution (48) containing ${ }^{32} \mathrm{P}$-labeled probes at $2 \times 10^{6} \mathrm{cpm} / \mathrm{ml}$. After overnight hybridization at $42^{\circ} \mathrm{C}$, membranes were washed in $4 \times$ SSC $(1 \times$ SSC is $150 \mathrm{mM} \mathrm{NaCl}$ plus $15 \mathrm{mM}$ sodium citrate) $-0.2 \%$ sodium dodecyl sulfate (SDS) at $55^{\circ} \mathrm{C}$. Hybridization with the $\beta$-galactosidase probe was carried out in $50 \%$ (vol/vol) formamide solution, and the membranes were washed in $0.5 \times \mathrm{SSC}-0.2 \%$ SDS at $65^{\circ} \mathrm{C}$.

\section{RESULTS}

Localization of a liver-specific enhancer in the rat cholesterol $7 \alpha$-hydroxylase gene. Figure 1 shows the $5^{\prime}$-flanking region of the rat $7 \alpha$-hydroxylase gene and the structures of five $7 \alpha$-hydroxylase-CAT chimeric genes which were used to localize DNA sequences necessary for the transcription of the $7 \alpha$-hydroxylase gene in a liver-specific manner. Nucleotide +1 corresponds to the transcription initiation site as defined by primer extension and S1 nuclease analysis of the rat mRNA (data not shown) and differs by 1 nucleotide from the site described by Jelinek and Russell (27). Five chimeric genes were created by placing different parts of the rat $7 \alpha$-hydroxylase 5'-flanking region in front of the coding region of the CAT gene. As a recipient cell line, we used a temperature-sensitive, SV40-transformed mouse hepatocyte cell line, H2.35 (56), that has been shown to be extremely useful in the study of liver-specific functions. When $\mathrm{H} 2.35$ cells are cultured under the dedifferentiating conditions (see Materials and Methods), the cells assume a flat structure and transcribe liver-specific genes such as albumin at very low rates. When cultured at the differentiating conditions, the cells exhibit a cuboidal structure, and the transcription of a subset of liver-specific genes is increased selectively $(31,56)$.

As shown in Fig. 1, when stably transfected $\mathrm{H} 2.35$ cells were cultured under dedifferentiating conditions, plasmid $\mathrm{pR} 7 \alpha$ CAT- 9 consistently produced the highest ratio of CAT/ $\beta$ galactosidase activity. Most importantly, when cells were cultured under differentiating conditions CAT activity was increased (an average of fourfold) only in cells transfected with pR7 $\alpha$ CAT-9. CAT activity for all other cell lines did not show any noticeable differences between the two culture conditions. These results indicated that the fragment -7454 to -6265 located at the very $5^{\prime}$ end of pR7 $\alpha$ CAT-9, which is deleted in pR $7 \alpha$ CAT- 8 , acts as a liver-specific enhancer of $7 \alpha$-hydroxylase transcription.

To study whether the DNA sequences located between -6265 and -342 were in fact dispensable for $7 \alpha$-hydroxylase transcription as suggested by the experiments in Fig. 1, we deleted these sequences, placing the $7 \alpha$-hydroxylase enhancer in front of the promoter fragment in pR7 $\alpha$ CAT-5, to generate p $7 \alpha$ E-R $7 \alpha$ CAT-5 (Fig. 2A). When $\mathrm{H} 2.35$ cells transfected with this chimeric gene were cultured under dedifferentiating and differentiating conditions, a level of induction of CAT activity (Fig. 2C), upon hepatocyte differentiation, comparable to that with cells transfected with pR7 $\alpha$ CAT-9 was observed. The ratios of $\mathrm{CAT} / \beta$-galactosidase activities in cells transfected with pR7 $\alpha$ CAT -9 or p $7 \alpha E-R 7 \alpha C A T-5$ were equivalent. p $7 \alpha \mathrm{E}$ $\mathrm{R} 7 \alpha \mathrm{CAT}-5$ has the $7 \alpha$-hydroxylase enhancer in the reverse orientation, and similar induction under differentiating condi- 


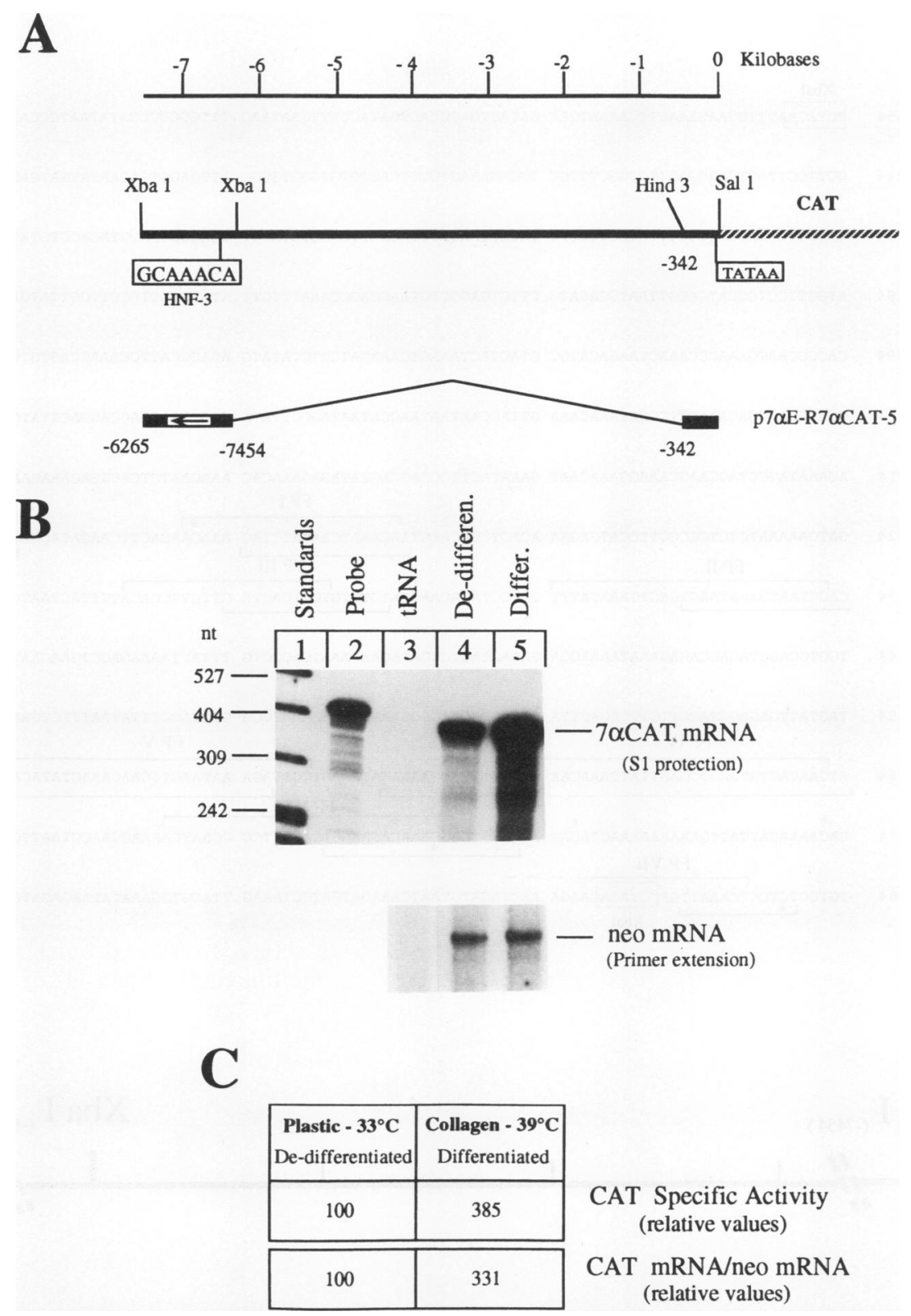

FIG. 2. Promoter activity and S1 nuclease mapping of the transcription initiation site of the $7 \alpha$-hydroxylase promoter-CAT chimeric gene in H2.35 cells transfected with p $7 \alpha E-R 7 \alpha C A T-5$. (A) Scheme of the internally deleted p $7 \alpha E-R 7 \alpha C A T-5$ construct containing the rat $7 \alpha$-hydroxylase enhancer (in the reverse orientation) in front of $342 \mathrm{bp}$ of the proximal promoter. $\mathrm{H} 2.35$ cells were transfected and cultured as explained in Materials and Methods, in duplicate dishes under dedifferentiating and differentiating conditions. One set of dishes was processed for CAT activity, and another was used to prepare RNA. (B) RNAs from dedifferentiated (lane 4) and differentiated (lane 5) cells and tRNA as a control were used to quantify $7 \alpha C A T$ mRNA by S1 nuclease analysis, with Neo mRNA as a control, as explained in Materials and Methods. Standards shown on the left in nucleotides (nt) were derived from an MspI digest of pBR322. (C) Relative values of CAT specific activity and CAT mRNA normalized to Neo mRNA. A Betagen analyzer was used to directly measure counts per minute per band.

tions was observed when the enhancer was placed in the same orientation as the endogenous gene (data not shown).

To determine whether the increase in CAT activity, upon hepatocyte differentiation, is a reflection of the amount of CAT mRNA and whether the initiation site used in the p7 $\alpha$ E-R7 $\alpha$ CAT-5-transfected cells corresponded to the initiation site used by the endogenous rat $7 \alpha$-hydroxylase mRNA, we performed $\mathrm{S} 1$ nuclease analysis with RNAs isolated from those cells grown under both conditions. As a probe, we used a single-stranded DNA fragment that encompasses the tran- scriptional initiation site, and as a control, we quantified Neo mRNA by the primer extension technique. Figure 2B shows that the amount of CAT mRNA increased approximately threefold upon differentiation (lanes 4 and 5), and the length of the protected fragments indicated that the hybrid mRNA was initiated at the appropriate position.

Nucleotide sequence of the $7 \alpha$-hydroxylase gene enhancer. Figure $3 \mathrm{~A}$ shows the nucleotide sequence of the $7 \alpha$-hydroxylase enhancer region ( -7454 to -6264 from the transcriptional initiation site). Examination of the enhancer region by 
A

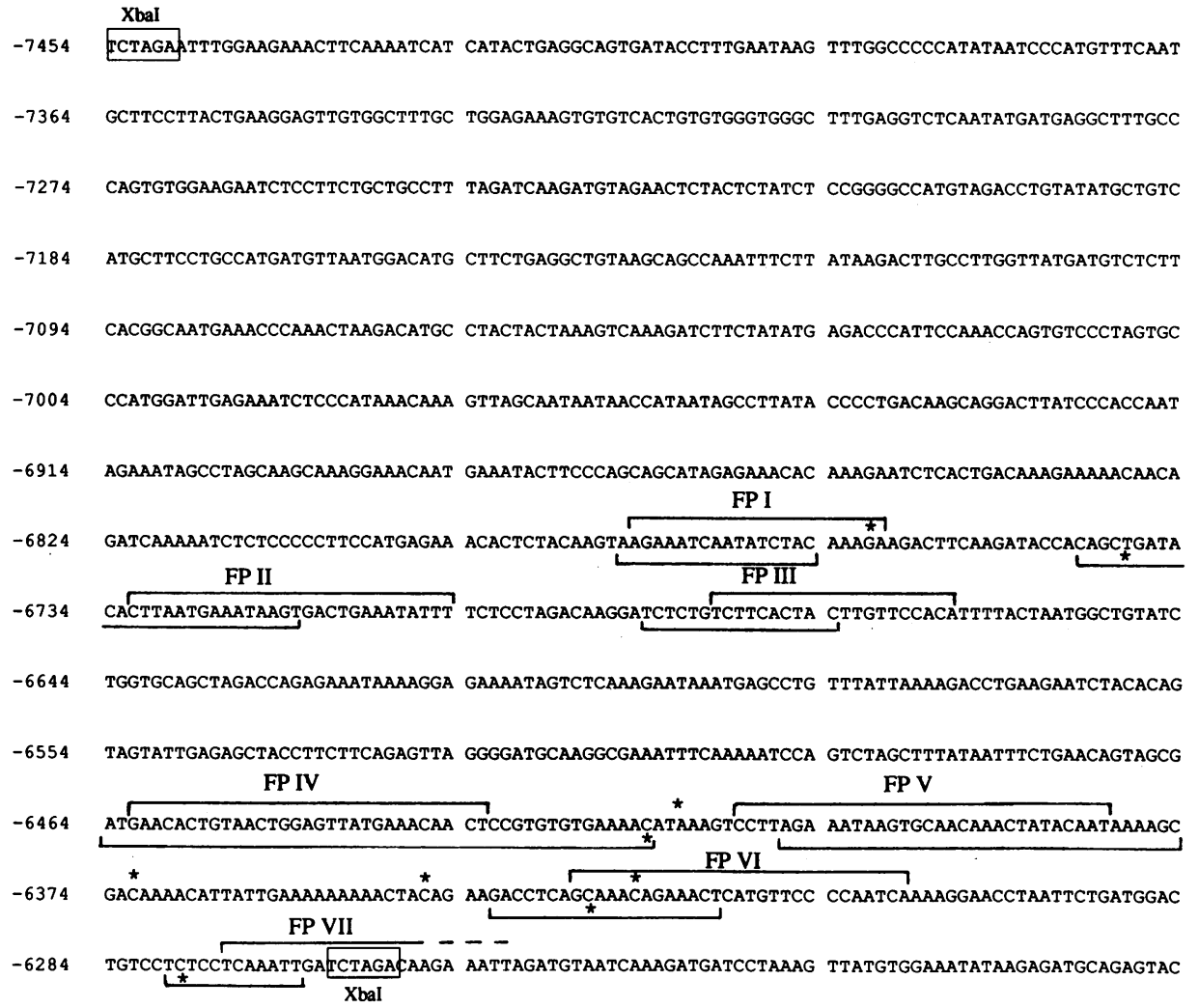

B
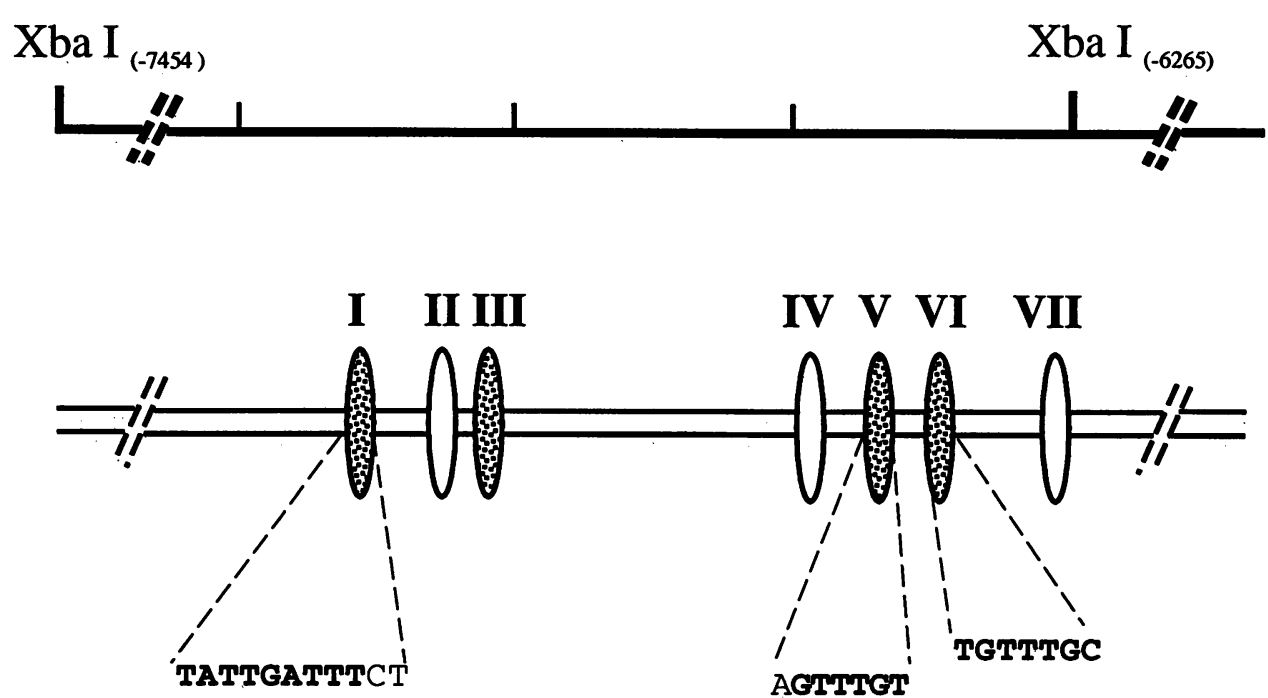

FIG. 3. Sequence and schematic representation of the rat $7 \alpha$-hydroxylase enhancer region. (A) The $X b a I$ sites (at positions -7454 and -6265 ) are boxed. Regions (FP I to FP VII) protected for DNase I digestion by nuclear extracts are underlined (for the bottom strand) and overlined (for the top strand). Asterisks, positions of DNase I-hypersensitive cleavage sites. (B) Footprint sites (FP I, FP III, FP V, and FP VI) which were observed only with liver nuclear extracts (stippled ovals) and sites (FP II, FP IV, and FP VII) that were detected with extracts from both livers and kidneys (open ovals) are depicted diagramatically on the XbaI (-7454)-to-XbaI (-6265) enhancer region. An 11-bp sequence closely related to TTR-HNF-3 consensus [TATTGA(T/C)TTA/TG] within the FP I protection site is shown. Homologies with TGT3-HNF-3 consensus [T(G/A)TTTG(C/T)] located within FP V and FP VI are shown, and the nucleotides representing identical matches are boldfaced. 


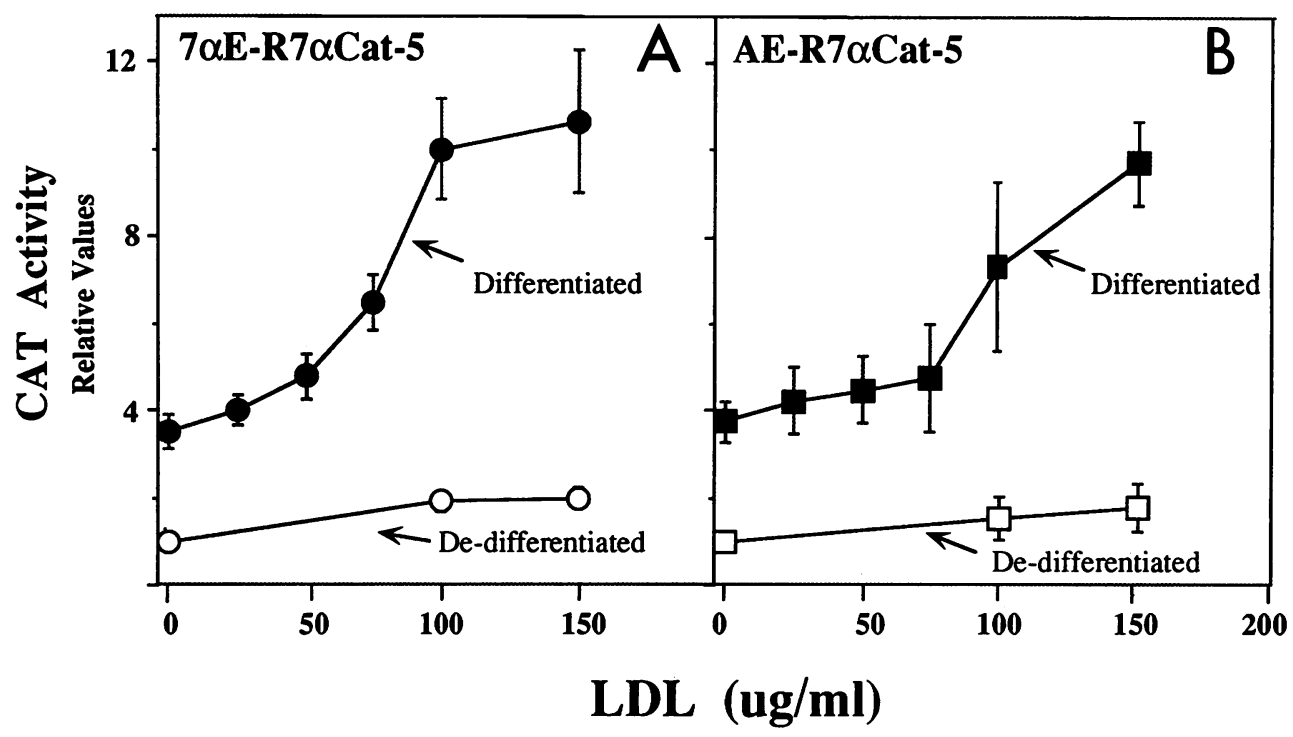

FIG. 4. LDL-mediated induction of CAT activity in H2.35 cells transfected with p $2 \alpha \mathrm{E}-\mathrm{R} 7 \alpha \mathrm{CAT}-5$ and pAE-R7 $\alpha \mathrm{CAT}-5$. H2.35 cells were transfected with p7 $\alpha$ E-R7 $\alpha$ CAT-5 (A) or pAE-R7 $\alpha$ CAT-5 (B) and selected for G418 resistance as explained in Materials and Methods. For the experiments, cells were seeded as explained in Materials and Methods, except that 60 -mm-diameter dishes were used, and $4 \times 10^{5}$ or $10^{6}$ cells were seeded per plastic or collagen dish, respectively. The indicated concentrations of LDL were added at the time of medium change. For the dedifferentiated cells lipoprotein-deficient serum was used instead of fetal calf serum when LDL was added. Average values for three experiments done with two different transfections are shown, relative to the values of cells grown under dedifferentiating conditions, in the absence of LDL. Bars, standard errors of the means.

DNase I footprinting analysis using liver nuclear extracts revealed seven protection sites (data not shown). Exact locations of those footprint sites are shown on the enhancer sequence (Fig. 3A). Footprints FP II, FP IV, and FP VII were also detectable with kidney nuclear extract at least on one strand, although the levels of protection were lower. On the other hand, four regions corresponding to FP I, FP III, FP V, and FP VI were protected only with liver extract on both strands. Additionally, several hypersensitive sites (indicated by asterisks on the DNA sequence in Fig. 3A) were also observed near or within the protected sites.

Figure 3B shows a schematic summary of the nuclear protein binding sites in the $7 \alpha$-hydroxylase enhancer. The sequence homologies between the sites protected by liver nuclear extract but not by kidney extract (FP I, FP V, and FP VI) and known liver-specific factor-binding sites are also illustrated. The FP III site showed no homology with known binding sites. An 11-bp sequence closely related to the transthyretin-hepatocyte nuclear factor 3 (TTR-HNF-3) consensus [TATTGA(T/ C)TTA/TG] (10) found within the FP I protection site is shown. Similarly, homologies with TGT3-HNF-3 consensus [T(G/A)TTTG(C/T)] (22) located within FP V and FP VI are shown. The exact nature of the factor(s) that binds to those sites is under investigation.

LDL up-regulates transcription of the $7 \alpha$-hydroxylase proximal promoter with either the mouse albumin enhancer or the $7 \alpha$-hydroxylase enhancer. The protein binding sites located within the $7 \alpha$-hydroxylase enhancer suggested to us that perhaps both enhancers are functionally similar. To study whether the $7 \alpha$-hydroxylase enhancer could be substituted functionally by the albumin enhancer, we constructed a hybrid plasmid, pAE-R7 $\alpha$ CAT-5. This plasmid contains the liver-specific enhancer from the mouse albumin gene described by Pinkert et al. (43), encompassing the NheI-Bam HI fragment extending from -10.4 to $-8.5 \mathrm{~kb}$, which also functions on the albumin proximal promoter in $\mathrm{H} 2.35$ cells (56). We inserted this fragment into pR7 $\alpha$ CAT-5 just upstream of the $7 \alpha$-hydroxylase promoter. This chimeric gene was transfected into $\mathrm{H} 2.35$ cells and cultured under either dedifferentiating or differentiating conditions as described above.

The data in Fig. 4B demonstrate that the albumin enhancer stimulated transcription of the $7 \alpha$-hydroxylase promoter (fourto fivefold) in differentiated $\mathrm{H} 2.35$ cells compared with dedifferentiated cells. This activation was similar to the one by the $7 \alpha$-hydroxylase enhancer in the chimeric gene p $7 \alpha$ E-R7 $\alpha$ CAT-5 (Fig. 2 and 4A). More importantly, when cells transfected with either one of these chimeric genes were cultured in the presence of increasing concentrations of human LDL, CAT activity rose between 2- and 2.5-fold in differentiated cells. In dedifferentiated cells lower activation, if any, was shown, suggesting that the factor(s) involved in that process is probably expressed at higher levels in differentiated $\mathrm{H} 2.35$ cells.

Incubation of those cell lines, $\mathrm{H} 2.35$ transfected with p7 $\alpha \mathrm{E}$ R7 $\alpha$ CAT-5 or pAE-R7 $\alpha$ CAT-5 or H2.35 transfected with pAER7 $\alpha$ Gal-3 (see Materials and Methods and below) with bile acids showed only 2 -fold regulation, at best, of the transcription of the rat $7 \alpha$-hydroxylase gene under all the conditions tested (28), which is far from the 5- to 10 -fold regulation in vivo.

Expression of albumin enhancer-7 $\alpha$-hydroxylase promoterlacZ fusion gene in transgenic mice mimics the cholesterol and bile acid-mediated regulation of the $7 \alpha$-hydroxylase gene. The lack of quantitative bile acid-mediated regulation of the expression of $7 \alpha$-hydroxylase promoter-CAT fusion genes in the tissue culture system explained above could be due to the fact that liver cells in culture often do not reproduce functions observed in vivo (56), or, as it has been suggested, posttranscriptional control plays a major part in that regulation $(52$, 55). To address these questions, we decided to use transgenic mice. Two fusion genes (Fig. 5) containing $1.6 \mathrm{~kb}$ of the 5 '-flanking region of the rat $7 \alpha$-hydroxylase gene were micro- 

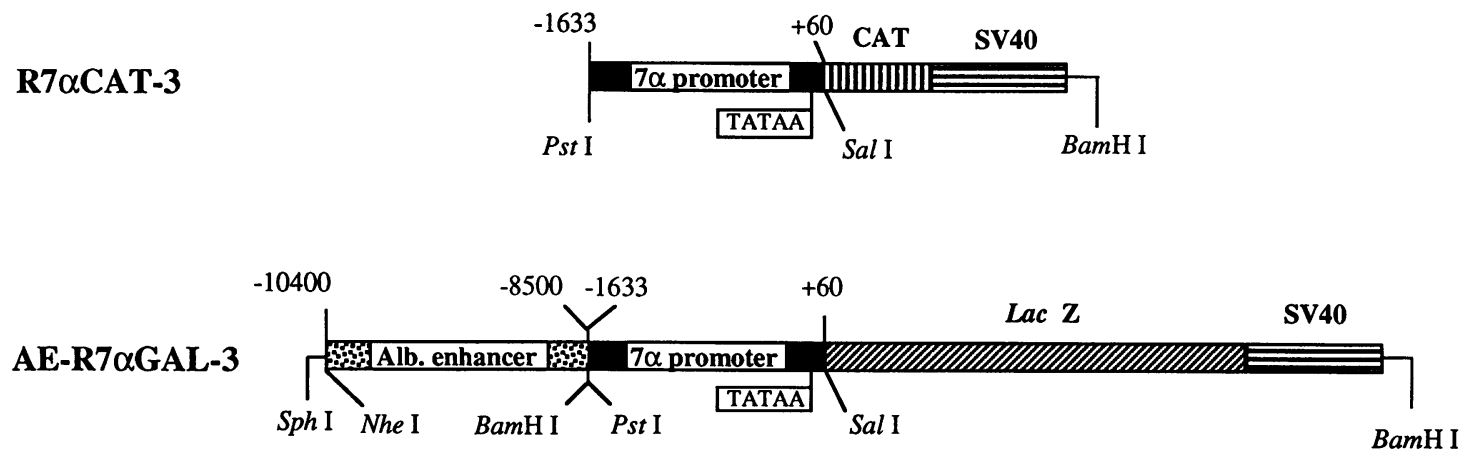

FIG. 5. Structures of the $7 \alpha$-hydroxylase promoter constructs used to generate transgenic mice. A 1.6-kb fragment from the 5 '-flanking region of the rat $7 \alpha$-hydroxylase gene is denoted by a solid bar. Nucleotide positions -1633 to +60 are numbered relative to the transcription initiation site of the rat $7 \alpha$-hydroxylase gene. The putative TATA box is shown. The -10.4 to $-8.5 \mathrm{~kb}$ mouse albumin enhancer region is represented by a stippled bar. The bacterial lacZ and CAT coding regions that were used as reporter genes and the SV40 t intron and polyadenylation site are indicated. Restriction sites used for the construction of the corresponding plasmids and for the preparation of the DNAs for microinjection are shown.

injected in mouse embryos and implanted in foster mothers. R $7 \alpha$ CAT-3 contains the $7 \alpha$-hydroxylase 5 '-flanking region in front of the CAT gene. AE-R $7 \alpha$ Gal-3 contains the mouse albumin enhancer in front of the $7 \alpha$-hydroxylase 5 '-flanking region and the lac $Z$ gene. Table 1 is a summary of the mice born as a result of those experiments. Of 47 mice screened for the presence of $\mathrm{R} 7 \alpha \mathrm{CAT}-3,8$ were positive, and they contained one to five copies of the transgene integrated into their genome. Expression experiments were performed with $F_{1}$ mice generated from each founder after the mice were fed a diet containing $5 \%$ colestipol (a diet that increases $7 \alpha$-hydroxylase mRNA [26]). We used nontransgenic mice from the same litters as controls. No CAT activity was detected in any of those mice.

Of 52 mice born as a result of the injection of $\mathrm{AE}-7 \alpha \mathrm{Gal}-3$ DNA, 16 contained the transgene, and the number of integrated copies ranged from 0.6 (presumably a mosaic mouse for the transgene) to 7 . Six of these transgenic founders were fed a diet containing $5 \%$ colestipol, killed, and tested for expression of $\beta$-galactosidase activity in liver extracts. Two of these founders $\left(\mathrm{F}_{0}-2\right.$ and $\left.\mathrm{F}_{0}-3\right)$ showed expression of the reporter gene. The remaining founders were mated, and $F_{1}$ mice were tested for expression as above. One mouse line (line 1) showed expression and was used for subsequent regulatory experiments. The proportion of founder mice expressing the transgene ( 1 in 5 ) can be considered average (42).

TABLE 1 . Summary of experiments with transgenic mice ${ }^{a}$

\begin{tabular}{lccccc}
\hline Construct & $\begin{array}{c}\text { No. of } \\
\text { pups tested }\end{array}$ & $\begin{array}{c}\text { No. } \\
\text { positive }\end{array}$ & $\begin{array}{c}\text { Expressing } \\
\text { founder } \\
\left(\mathrm{F}_{0}\right) \text { line }\end{array}$ & $\begin{array}{c}\text { No. of } \\
\text { genes/cell }\end{array}$ & $\begin{array}{c}\text { Reporter } \\
\text { activity }^{c}\end{array}$ \\
\hline R7 $\alpha$ CAT-3 & 47 & 8 & & $1-5$ & ND \\
& & & & 1 & 16.4 \\
AE-7 $\alpha$ Gal-3 & 52 & 16 & 1 & 1 & 1.6 \\
& & & 2 & 0.6 & 2.2 \\
\hline
\end{tabular}

${ }^{a}$ Mouse embryos were microinjected with fusion genes R7 $\alpha$ CAT-3 or AE$7 \alpha$ Gal-3. Pups born were tested for transgenicity by Southern blot analysis. $\beta-$ Galactosidase activity was measured in liver extracts as described in Materials and Methods.

${ }^{b}$ Number of copies of the inserted DNA per genome, estimated from Southern blots.

${ }^{c}$ In milliunits per milligram of protein. All animals were colestipol fed. For founder 1 , two mice from the $F_{1}$ generation were tested. Founders 2 and 3 were killed and tested. ND, not detectable.
To study whether the expression of the reporter gene in line 1 mice was restricted to the liver, as is the case for the endogenous rat $7 \alpha$-hydroxylase gene (26), protein extracts were prepared from the livers, brains, heart, kidneys, and lungs of animals fed a regular diet. As shown in Fig. 6, $\beta$-galactosidase activity was clearly detectable in the liver, very low in the heart, and undetectable in brain, kidney, and lung extracts. Curiously, liver expression in males was fourfold higher than in females (see Discussion).

The regulation of the expression of the albumin enhancer$7 \alpha$-hydroxylase-lac $Z$ transgene was examined by monitoring changes in $\beta$-galactosidase activity in response to different dietary manipulations that are known to control rat hepatic $7 \alpha$-hydroxylase. Mice were fed regular chow (normal diet) or chow supplemented with colestipol, cholesterol, or bile acids for 5 to 14 days, and both soluble protein extracts and total RNA were prepared as described in Materials and Methods. The results are shown in Fig. 7. Quantitatively equivalent levels of regulation were observed for mice of both sexes, although $\beta$-galactosidase activity was higher (three- to fourfold on average) in males than in females under all tested dietary

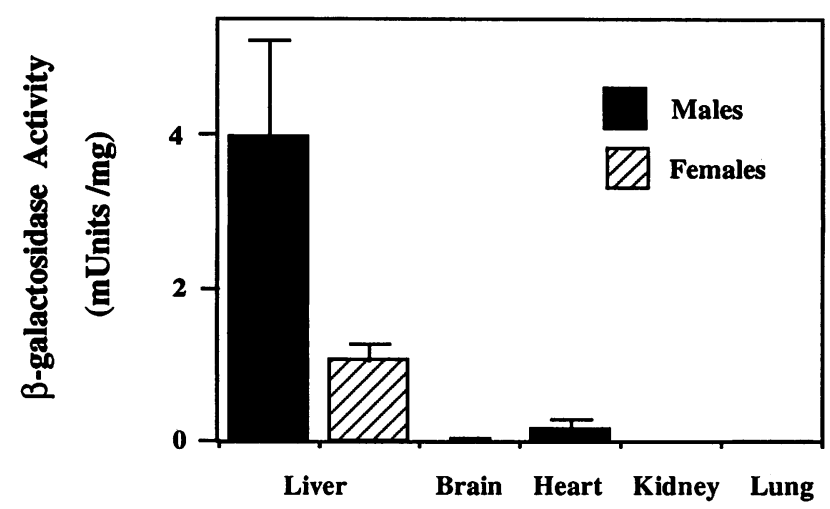

FIG. 6. Expression of the $7 \alpha$-hydroxylase-lac $Z$ transgene in different tissues. $\beta$-Galactosidase activity was measured in liver, brain, heart, kidney, and lung extracts as described in Materials and Methods. Transgenic male or female mice from line 1 were kept on a regular chow diet and killed between the 6th and 8 th $\mathrm{h}$ of the dark period. The data are means with standard errors of the means for five animals each. 


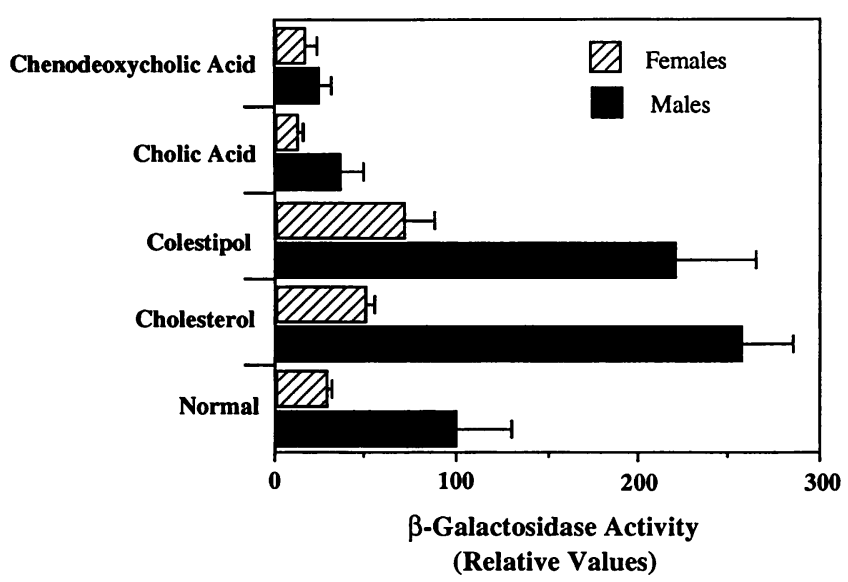

FIG. 7. Dietary regulation of albumin enhancer-7 $\alpha$-hydroxylaselac $Z$ fusion gene expression. Animals were fed the indicated diets as described in Materials and Methods. $\beta$-Galactosidase activity was measured in liver extracts of 6- to 8-weeks-old male or female mice as described in Materials and Methods. The data are means with standard errors of the means for five to seven mice, expressed as relative numbers normalized to the values for normally fed males $(4 \mathrm{mU} / \mathrm{mg}$ of protein).

conditions (see Discussion). Cholesterol feeding elevated $\beta$-galactosidase activity 2.5 -fold in males $(P \leq 0.005)$ and 2 -fold in females $(P \leq 0.025)$, compared with mice fed a normal diet. This correlates well with results in our tissue culture system (Fig. 4). Similar induction was observed by colestipol feeding of male (2.2-fold; $P \leq 0.05)$ or female (2.7-fold; $P \leq 0.025)$ mice, compared with mice fed a normal diet. Cholic acid feeding, on the other hand, reduced $\beta$-galactosidase activity in both males (2.9-fold; $P \leq 0.05)$ and females (2.4-fold; $P \leq 0.005)$. Chenodeoxycholic acid feeding also reduced $\beta$-galactosidase activity in both males (4.3-fold; $P \leq$ 0.025 ) and females. Most significantly, in males the level of $\beta$-galactosidase activity in colestipol-fed mice (which corresponds to the lowest level of bile acids in the liver) was 6.5 -fold $(P \leq 0.005)$ higher than in cholic acid-fed mice and 9.5 -fold $(P$ $\leq 0.005)$ higher than in chenodeoxycholic acid-fed mice. Likewise, female colestipol-fed mice showed 6.5-fold $(P \leq$ $0.005)$ higher $\beta$-galactosidase activity than cholic acid-fed mice and 4.6-fold $(P \leq 0.05)$ higher than chenodeoxycholic acid-fed mice.

To confirm that those changes in $\beta$-galactosidase activity were a reflection of variations in the level of $\beta$-galactosidase mRNA and to determine whether expression of the endogenous $7 \alpha$-hydroxylase mRNA was similarly regulated, we quantified $\beta$-galactosidase mRNA and $7 \alpha$-hydroxylase mRNA in poly $(\mathrm{A})^{+}$RNA pools prepared from equal amounts of total RNA from each mouse by slot blot analysis (Fig. 8). To normalize the amount of loaded RNA, we also quantified albumin mRNA. We used RNA from nontransgenic mice from the same litters as a negative control. Three single-stranded probes corresponding to the three mRNAs were used as described in Materials and Methods.

As indicated in Fig. 8, $\beta$-galactosidase mRNA levels showed a pattern of induction by cholesterol and colestipol, and of suppression by cholic acid, similar to the enzymatic activity. The level of $\beta$-galactosidase mRNA in males was also higher than that in females under all the dietary conditions. Regulation of $7 \alpha$-hydroxylase mRNA was very similar, with the exception that no difference in the level of $7 \alpha$-hydroxylase
mRNA was observed between males and females under any dietary condition. With these assay conditions, the $7 \alpha$-hydroxylase mRNA in females fed colestipol showed a sixfold increase with respect to normal females (Fig. 8A), in disagreement with the regulation observed for the $\beta$-galactosidase activity and mRNA. However, when the $7 \alpha$-hydroxylase mRNA was quantified in the individual total RNA samples rather than in the pooled poly $(\mathrm{A})^{+}$RNAs, a twofold induction was observed (Fig. 8B), in agreement with the $\beta$-galactosidase activity and endogenous $7 \alpha$-hydroxylase mRNA.

\section{DISCUSSION}

It is common for liver-specific genes not to be expressed and/or regulated in tissue culture systems in a manner similar to that of the entire animal (56). Also, conditions such as tissue-specific expression and cholesterol homeostasis require whole animal models to study the complex interactions of whole organ systems. In this study we have used two experimental approaches to study the mechanisms by which cholesterol and bile acids regulate expression of the $7 \alpha$-hydroxylase gene. First, we used a mouse hepatocyte-derived cell line, $\mathrm{H} 2.35$, that can be propagated in a dedifferentiated state and then induced to the differentiated state at will (56). The biological significance of this induction is emphasized by the enhanced transcription of a number of liver-specific genes, such as albumin and several liver-specific trans-acting factors $(25,31,56,57)$, but not of genes encoding actin or rRNA (56). Using this system, we have localized a liver-specific enhancer located $7 \mathrm{~kb}$ upstream of the transcriptional initiation site of the rat $7 \alpha$-hydroxylase gene. We also showed that LDL mediates transcriptional activation of chimeric genes, containing either the $7 \alpha$-hydroxylase or the albumin enhancer in front of the $7 \alpha$-hydroxylase proximal promoter, to the same extent as the in vivo cholesterol-mediated regulation of $7 \alpha$-hydroxylase mRNA. However, in that tissue culture system bile acids only partially (twofold, at best) regulated rat $7 \alpha$-hydroxylase promoter activity. These limitations persuaded us to use transgenic mice to study the molecular mechanisms involved in the regulation of $7 \alpha$-hydroxylase expression. Using that approach, in this article we demonstrate that the promoter region of the rat $7 \alpha$-hydroxylase gene mediates the regulation of its transcription by bile acids and cholesterol. This regulation is quantitatively similar to that of the endogenous mouse $7 \alpha-$ hydroxylase gene and of the rat $7 \alpha$-hydroxylase gene $(7,26$, 53), indicating that posttranscriptional modification does not play a major role, if any.

Several lines of evidence have led us to conclude the existence of a liver-specific enhancer, $7 \mathrm{~kb}$ upstream from the transcriptional initiation site, in the $7 \alpha$-hydroxylase gene. First, cells transfected with pR7 $\alpha$ CAT-9, the construct containing the longest $7 \alpha$-hydroxylase 5 '-flanking region, has fourfold higher CAT activity under dedifferentiating conditions than cells transfected with pR7 $\alpha \mathrm{CAT}-8$, which lacks the 1.2-kb XbaI fragment from the far 5'-flanking region. All other 5' deletion mutants studied showed levels of expression similar to that of pR7 $\alpha$ CAT- 8 (Fig. 1). More importantly, when transfected $\mathrm{H} 2.35$ cells were induced to differentiate to hepatocyte-like cells, only pR7 $\alpha$ CAT -9 showed higher expression (fourfold), presumably due to an increase in the rate of transcription. This was quantitatively similar to the induction of albumin transcription in the same cells (56). Third, cells transfected with an internally deleted mutant, p $7 \alpha$ E-R7 $\alpha$ CAT-5, that places the putative enhancer in front of the $342 \mathrm{bp}$ of proximal promoter showed levels of increased expression upon differentiation that were similar to that for pR7 $\alpha$ CAT-9 (Fig. 2). Quantification of 
A

\begin{tabular}{|c|c|c|c|c|c|c|}
\hline & \multicolumn{3}{|c|}{ Males } & \multicolumn{3}{|c|}{ Females } \\
\hline Diets Probes & gal & $7 \alpha$ & Albumin & gal & $7 \alpha$ & Albumin \\
\hline Normal & - & - & & 2 & - & \\
\hline Cholesterol & - & $=$ & & - & - & \\
\hline Colestipol & - & $\infty$ & & - & 6 & \\
\hline Cholic Acid & & & & & - & \\
\hline Control & & - & & & & \\
\hline
\end{tabular}

FIG. 8. Dietary regulation of $7 \alpha$-hydroxylase and $\beta$-galactosidase mRNA levels in mouse liver. Poly $(A)^{+}$RNA was isolated from pooled total RNA from livers of male and female mice fed the indicated diets as described in Materials and Methods. Slot blots were hybridized with ${ }^{32} \mathrm{P}$-labeled probes for $\beta$-galactosidase [with $2.5 \mu \mathrm{g}$ of poly $(\mathrm{A})^{+} \mathrm{RNA}$ ], $7 \alpha$-hydroxylase [with $2.5 \mu \mathrm{g}$ of poly $(\mathrm{A})^{+}$RNA or $10 \mu \mathrm{g}$ of total RNA], and albumin [with $0.5 \mu \mathrm{g}$ of poly $(\mathrm{A})^{+} \mathrm{RNA}$ ] as a control. Nylon membranes were exposed to X-ray film (A) for either 9 days $(\beta$ galactosidase [gal]) or $24 \mathrm{~h}$ at $-70^{\circ} \mathrm{C}(7 \alpha$-hydroxylase $[7 \alpha])$ with intensifying screens or $24 \mathrm{~h}$ at room temperature with no screen (albumin). Radioactive bands were quantified (B) by using a PhosphorImager (Molecular Dynamics) after a 24-h exposure and normalized with respect to albumin mRNA. The value for colestipol-fed females was obtained by averaging the individual total RNA samples rather than the pooled poly $(\mathrm{A})^{+}$RNAs. The values are relative to those for normally fed males. $\beta$-Galactosidase mRNA from cholic acid-fed female mice was undetectable. RNA from nontransgenic mice was used as a negative control.

B

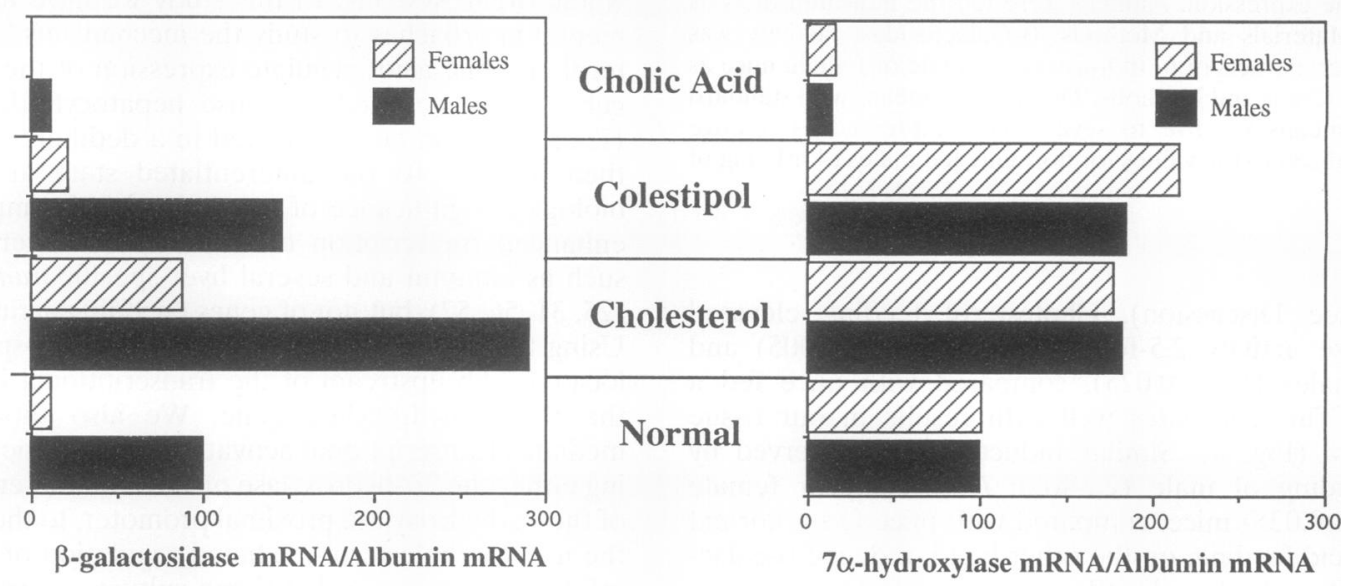

(Relative Values)

(Relative Values)

mRNA by $\mathrm{S} 1$ nuclease techniques confirmed that the induction upon differentiation was due to an increase in the amount of $7 \alpha$-hydroxylase-CAT mRNA, and this mRNA was initiated at the same place as the endogenous rat $7 \alpha$-hydroxylase transcription initiation site (Fig. 2).

Another line of evidence that supports our finding of a liver-specific enhancer in the rat $7 \alpha$-hydroxylase gene derived from the DNA sequence and footprint analysis (Fig. 3 and data not shown) of the enhancer region and from the DNA sequence homologies found with the recognition sequences of a liver-specific trans-acting factor HNF-3 (Fig. 3B). Four regions within the $7 \alpha$-hydroxylase enhancer (FP I, III, V, and VI) were protected only by liver nuclear extracts (Fig. 3). The cluster of binding sites in the $7 \alpha$-hydroxylase enhancer resembles a similar cluster in the mouse albumin enhancer (31) and is a common characteristic of gene enhancers. Computer analysis of a data base containing the recognition sequences for liver-specific transcription factors revealed a $100 \%$ homology with an octanucleotide found in FP VI $(-6405$ to -6440$)$ and the consensus binding site $[\mathrm{T}(\mathrm{G} / \mathrm{A}) \mathrm{TTTG}(\mathrm{C} / \mathrm{T}) \mathrm{T}]$ for the TGT3-HNF3 factor (Fig. 4B), which occurs at the eH site of mouse albumin enhancer $(25,31)$ and other liver-specific genes $(17,22,34,36,50)$. Competition gel shift experiments also suggested that the same or homologous factor binds to the $\mathrm{eH}$ site of the albumin enhancer and to the FP VI site of the $7 \alpha$-hydroxylase enhancer (data not shown).
The final evidence supporting the existence of a liver-specific enhancer in the rat $7 \alpha$-hydroxylase gene comes from the studies with the albumin enhancer. We have demonstrated that the $7 \alpha$-hydroxylase enhancer region can be functionally substituted by another liver-specific enhancer, the mouse albumin enhancer (Fig. 4). This enhancer is essential for maximal expression of the albumin promoter in differentiated $\mathrm{H} 2.35$ cells $(56,57)$ and in transgenic mice $(43)$. Both basal activity and induction of the expression upon cell differentiation from chimeric genes that contain the $7 \alpha$-hydroxylase were equivalent to those from the genes containing the mouse albumin enhancer (Fig. 4). It has been suggested that the albumin enhancer may require its own promoter, because it did not function with the growth hormone promoter in transgenic mice (43). Here, however, we demonstrate that the albumin enhancer can, in fact, activate a heterologous promoter both in tissue culture cells (Fig. 4) and in transgenic mice (Fig. 5 to 8 and Table 1). This finding underlies the similarities between both enhancers. First, the trans-acting factor(s) that binds to both enhancers seems to be similar according to the sequence homology and the gel shift competition experiments discussed above. Second, the fact that the albumin enhancer can functionally substitute the $7 \alpha$-hydroxylase enhancer implies that both enhancers are capable of interacting with the $7 \alpha$-hydroxylase proximal promoter in vivo.

The $5^{\prime}$-flanking region of the human $7 \alpha$-hydroxylase gene 
has been isolated and functionally characterized with HepG2 cells as recipients (33). A liver-specific enhancer has been localized at position -432 to -220 , although no cholesterol or bile acid regulation has yet been shown to be mediated by this $5^{\prime}$-flanking region of the human $7 \alpha$-hydroxylase gene. It is interesting that the DNA sequence between -432 and -220 , which appears to confer cell specificity on the transcription of the human $7 \alpha$-hydroxylase gene, has only $51 \%$ homology with the rat $7 \alpha$-hydroxylase promoter and several of the relevant regulatory elements found in the human promoter are missing in the rat (33). Homologous elements (HNF-3 motifs) are found in the rat enhancer located $7 \mathrm{~kb}$ upstream of the transcriptional initiation site as described in this article (Fig. 3 ). It seems that perhaps evolution has placed that enhancer closer to the proximal promoter in the human gene, although it cannot be ruled out that the human gene contains another enhancer at a position similar to that of the rat gene.

Expression of chimeric genes, containing the $7 \alpha$-hydroxylase proximal promoter with either its own enhancer or the albumin enhancer, is induced up to 2.5 -fold in differentiated cells incubated in the presence of LDL (Fig. 4). The concentrations of LDL used $(25$ to $150 \mu \mathrm{g} / \mathrm{ml})$ are well below the average plasma LDL levels both in humans (approximately 1,200 $\mu \mathrm{g} / \mathrm{ml}$ ) and in other mammals (approximately $320 \mu \mathrm{g} / \mathrm{ml}$ ) (19). Considering that the concentration of LDL in the interstitial fluid of humans is on the order of $10 \%$ of that in plasma, the LDL concentrations that we used are well below what can be considered physiological (19). In the absence of either one of these enhancers, regulation could not be observed (28), suggesting that interactions between the $7 \alpha$-hydroxylase or albumin enhancers with the $7 \alpha$-hydroxylase promoter are necessary for LDL-mediated regulation of $7 \alpha$-hydroxylase transcription. This idea is in agreement with our observations that a common element(s) may be present in both enhancers. An alternative explanation could be that liver-specific activation, induced by either enhancer, is essential for LDL-mediated induction of $7 \alpha$-hydroxylase transcription. This regulation in our tissue culture system mimics the cholesterol-mediated induction of $7 \alpha$-hydroxylase expression in rat liver $(26,30)$. Although we cannot rule out that components of LDL other than cholesterol might be the regulatory factor, the fact that the same level of regulation has been observed in the entire animal upon cholesterol feeding suggests that the effector is cholesterol. 25-Hydroxy cholesterol, the most potent sterol that downregulates 3-hydroxy-3-methylglutaryl-coenzyme A reductase and LDL receptor transcription in tissue culture cells $(3,4)$, failed to show any effect on $7 \alpha$-hydroxylase gene expression in our tissue culture system, suggesting that the active sterol that up-regulates $7 \alpha$-hydroxylase transcription is different from the sterol that down-regulates those two other genes. This is in agreement with the lack of significant homology between the sterol regulatory elements in the promoter region of those genes $(3,40)$ and the $7 \alpha$-hydroxylase promoter, which suggests that the trans-acting factor(s) involved in the cholesterolmediated induction of $7 \alpha$-hydroxylase transcription is different from the factor(s) involved in the suppression of 3-hydroxy-3methylglutaryl-coenzyme A reductase and LDL receptor transcription. The LDL-mediated regulation was observed only in differentiated $\mathrm{H} 2.35$ cells, suggesting that the factor(s) involved in that process is expressed specifically in differentiated hepatocytes.

Since we could not quantitatively reproduce the bile acidmediated regulation in our tissue culture system, we chose to address that question by using transgenic mice. We introduced two $7 \alpha$-hydroxylase 5 '-flanking region-reporter fusion genes (Fig. 5) containing $1.6 \mathrm{~kb}$ of the $5^{\prime}$-flanking region and 59 nucleotides of the $5^{\prime}$-untranslated region of the rat $7 \alpha$-hydroxylase gene into the mouse genome. We used either the bacterial CAT gene (R7 $\alpha \mathrm{CAT}-3)$ or the lac $Z$ gene (AE$\mathrm{R} 7 \alpha \mathrm{Gal}-3$ ) as a reporter. AE-R7 $\alpha \mathrm{Gal}-3$ also contained the mouse albumin enhancer upstream of the $7 \alpha$-hydroxylase 5 -flanking region. The mouse albumin enhancer was chosen because it has been proven to be highly active in transgenic mice (43) and it was at least as active as the $7 \alpha$-hydroxylase enhancer in tissue culture (Fig. 1, 2, and 4). The use of two different reporter genes was circumstantial, and both genes have been successfully used as reporters to study many different promoters in transgenic mice $(42,44)$.

Several new insights can be deduced from our studies with transgenic mice. First, transcription of the $7 \alpha$-hydroxylase gene seems to require the presence of a liver-specific enhancer in vivo. Only transgenic mice carrying the AE-R7 $\alpha \mathrm{Gal}-3$ gene expressed the reporter gene (Table 1), supporting our tissue culture experiments which indicate that either the $7 \alpha$-hydroxylase enhancer or the albumin enhancer is necessary for transcription of the $7 \alpha$-hydroxylase promoter (Fig. 1, 2, and 4).

Second, our results indicate that the cholesterol and bile acid-mediated regulation of $7 \alpha$-hydroxylase expression is transcriptional and most, if not all, of the regulation can be accounted for by that mechanism. This is deduced from a direct comparison of the extent of regulation of $\beta$-galactosidase activity (Fig. 7) and mRNA (Fig. 8) and endogenous $7 \alpha$-hydroxylase mRNA levels, from both rats $(7,26,53)$ and mice (Fig. 8) under the different dietary conditions tested. Thus, the regulation between colestipol-induced mice and cholic- or chenodeoxycholic acid-suppressed mice is 5- to 9.5-fold for $\beta$-galactosidase activity and 12 -fold for $\beta$-galactosidase mRNA, compared with 13-fold for the endogenous $7 \alpha$-hydroxylase mRNA.

A third insight derived from these studies is that the DNA elements that mediate both the cholesterol regulation and the bile acid regulation of $7 \alpha$-hydroxylase transcription are located in the $5^{\prime}$-flanking region of the gene. Since expression of the AE-R7 $\alpha$ Gal-3 transgene, which contains the albumin enhancer, is regulated in the same manner as that of the endogenous gene (Fig. 7 and 8), the enhancer region of the $7 \alpha$-hydroxylase gene, located $7 \mathrm{~kb}$ upstream of the transcriptional initiation site, does not seem to be involved in the regulation. Alternatively, similar interactions between the $7 \alpha-$ hydroxylase or the albumin enhancer with the $7 \alpha$-hydroxylase promoter could be involved in the regulation. This is in agreement with the data that we obtain with tissue culture for the cholesterol-mediated regulation (Fig. 4). It should be noted that albumin expression is not subject to cholesterol or bile acid regulation (Fig. 8) (16), a finding which rules out the possibility that the observed regulation is mediated by the albumin enhancer. It is still possible that the regulation that we have observed is due to some fortuitous combination of sequences generated by the artificial albumin enhancer-7 $\alpha$ hydroxylase chimeric promoter or to the site of chromosomal integration. The fact that the regulation of the expression of the reporter gene parallels, almost identically, the regulation of the endogenous gene (Fig. 7 and 8 ) by cholesterol, colestipol, and bile acids makes those possibilities very unlikely. Furthermore, preliminary experiments with a deleted version of the albumin enhancer- $7 \alpha$-hydroxylase promoter construct in transgenic mice (thus having different junction sequences) show similar expression of the reporter gene, ruling out the above-mentioned possibilities.

Surprisingly, the level of $\beta$-galactosidase expression is between three- and fivefold higher in males than in females under all the dietary conditions tested (Fig. 7 and 8), whereas the 
endogenous $7 \alpha$-hydroxylase gene is expressed at similar levels in mice (Fig. 8) or even in a reverse manner in rats (53). There are two possible explanations for this observation. First, it is known that the place of chromosomal integration of the transgene plays a role in the level of its expression (42). Perhaps the transgene was integrated in a locus that is transcribed at higher levels in males than in females. The other possible explanation is that the transgene is more methylated in female than in male mice and lower expression in females is a reflection of that. This phenomenon has been previously reported particularly in a $\mathrm{C} 57 \mathrm{BL} / 6$ strain background. For example, Engler et al. (14) reported that a transgene [pHRD, containing target sequences for the $\mathrm{V}(\mathrm{D}) \mathrm{J}$ recombinase] was highly methylated in 12 independent mouse lines when introduced in a C57BL/6 strain background but became less methylated when bred into a DBA/2 background. Transgenes inherited from the mother are generally more methylated; however, this parental effect disappears following continued breeding into the nonmethylating strain. Swain et al. (54) have shown that a transgene containing both prokaryotic and eukaryotic DNA segments, none of which was derived from an authentically imprinted gene, was expressed exclusively from the paternal chromosome. The silent maternally inherited copies were highly methylated. Strain C $57 \mathrm{BL} / 6$ is the origin of the mouse strain used in our experiments as an embryo donor and for mating of founder mice (see Materials and Methods). Experiments are in progress to assess these two possibilities.

Although there are several examples of genes whose transcription is down-regulated by cholesterol (20) and the DNA elements involved in that suppression have been defined $(3,40$, 51), no information on DNA element(s) responsible for bile acid-mediated regulation of gene transcription is available. The availability of these expression systems provides a novel and important step towards elucidating the molecular mechanisms involved in the regulation of $7 \alpha$-hydroxylase transcription by cholesterol and bile acids.

\section{ACKNOWLEDGMENTS}

M.I.R., D.K., and D.H. contributed equally to this work.

We specially acknowledge Jose Teixeira for multiple discussions, suggestions, and a critical review of the manuscript. We are grateful to Ken Zaret for supplying the $\mathrm{H} 2.35$ cell line and plasmid pAN/T2-NB' containing the albumin enhancer and for numerous discussions and advice. We also thank Carlos B. Hirschberg and Reid Gilmore for useful discussions and critical reviews of the manuscript. We thank John Kulik from the University of Massachusetts Medical Center Transgenic Animal Core Facility for microinjections and embryo implantation.

This research was supported in part by a research grant from the National Institutes of Health (DK 44218) and a grant from Pfizer, Inc. G.G. is an Established Investigator of the American Heart Association. D.H. was the recipient of a postdoctoral fellowship from the Ministerio de Educación y Ciencia (Spain).

\section{REFERENCES}

1. Beck, E., G. Ludwig, E. A. Auerswald, B. Reiss, and H. Schaller. 1982. Nucleotide sequence and exact localization of the neomycin phosphotransferase gene from transposon Tn5. Gene 19:327-336.

2. Bradford, M. M. 1976. A rapid and sensitive method for the quantitation of microgram quantities of protein utilizing the principle of protein-dye binding. Anal. Biochem. 72:248-254.

3. Briggs, M. R., C. Yokoyama, X. Wang, M. S. Brown, and J. L. Goldstein. 1993. Nuclear protein that binds sterol regulatory element of low density lipoprotein receptor promoter. I. Identification of the protein and delineation of its target nucleotide sequence. J. Biol. Chem. 268:14490-14496.

4. Brown, M. S., and J. L. Goldstein. 1974. Suppression of 3-hydroxy- 3-methylglutaryl coenzyme A reductase activity and inhibition of growth of human fibroblasts by 7 -ketocholesterol. J. Biol. Chem. 249:7306-7314.

5. Carey, M. C., and M. J. Cahalene. 1988. Enterohepatic circulation, p. 573-616. In I. M. Arias et al. (ed.), The liver: biology and pathobiology. Raven Press, New York.

6. Chen, C. A., and H. Okayama. 1988. Calcium phosphate-mediated gene transfer: a highly efficient transfection system for stably transforming cells with plasmid DNA. BioTechniques 6:632-638.

7. Chiang, J. Y. L., W. F. Miller, and G.-M. Lin. 1990. Regulation of cholesterol $7 \alpha$-hydroxylase in the liver. Purification of cholesterol $7 \alpha$-hydroxylase and the immunochemical evidence for the induction of cholesterol $7 \alpha$-hydroxylase by cholesteryramine and circadian rhythm. J. Biol. Chem. 265:3889-3897.

8. Chirgwin, J. M., A. E. Przybyla, R. J. MacDonald, and W. T. Rutter. 1979. Isolation of biologically active ribonucleic acid from sources enriched in ribonuclease. Biochemistry 18:5294-5299.

9. Church, G. M., and W. Gilbert. 1984. Genomic sequencing. Proc. Natl. Acad. Sci. USA 81:1991-1995.

10. Costa, R. H., D. R. Grayson, and J. Darnell, Jr. 1989. Multiple hepatocyte-enriched nuclear factors function in the regulation of transthyretin and $\alpha 1$-antitrypsin genes. Mol. Cell. Biol. 9:14151425.

11. Danielsson, J. M., and J. Sjovall. 1975. Bile acid metabolism. Annu. Rev. Biochem. 44:233-253.

12. Deininger, P. L. 1983. Approaches to rapid DNA sequence analysis. Anal. Biochem. 135:247-263.

13. Dietschy, J. M. 1984. Regulation of cholesterol metabolism in man and in other species. Klin. Wochenschr. 62:338-345.

14. Engler, P., D. Haasch, C. A. Pinkert, L. Doglio, M. Glymour, R. Brinster, and U. Storb. 1991. A strain-specific modifier on mouse chromosome 4 controls the methylation of independent transgene loci. Cell 65:939-947.

15. Gil, G., M. S. Brown, and J. L. Goldstein. 1986. Cytoplasmic 3-hydroxy-3-methylglutaryl coenzyme A synthase from the hamster. II. Isolation of the gene and characterization of the 5' flanking region. J. Biol. Chem. 261:3717-3724.

16. Gil, G., and V. Esser. 1991. Cholesterol-mediated suppression of $\alpha 1$-inhibitor III, a plasma $\alpha$-macroglobulin family protein. J. Biol. Chem. 266:20512-20518.

17. Godbout, R., R. S. Ingram, and S. M. Tilghman. 1986. Multiple regulatory elements in the intergenic region between the $\alpha$-fetoprotein and albumin genes. Mol. Cell. Biol. 6:477-487.

18. Goldstein, J. L., S. K. Basu, and M. S. Brown. 1983. Receptormediated endocytosis of low-density lipoprotein in cultured cells. Methods Enzymol. 98:241-260.

19. Goldstein, J. L., and M. S. Brown. 1977. The low density lipoprotein receptor and its relation to atherosclerosis. Annu. Rev. Biochem. 46:897-930.

20. Goldstein, J. L., and M. S. Brown. 1990. Regulation of the mevalonate pathway. Nature (London) 343:425-430.

21. Gorman, C. M., L. F. Moffat, and B. H. Howard. 1982. Recombinant genomes which express chloramphenicol acetyltransferase in mammalian cells. Mol. Cell. Biol. 2:1044-1051.

22. Grange, T., J. Roux, G. Rigaud, and R. Pictet. 1991. Cell-type specific activity of two glucocorticoid responsive units of rat tyrosine aminotransferase gene is associated with multiple binding sites for C/EBP and a novel liver-specific nuclear factor. Nucleic Acids Res. 19:131-139.

23. Hogan, B., F. Constantini, and L. Lacy. 1986. Manipulating the mouse embryo. A laboratory manual. Cold Spring Harbor Laboratory, Cold Spring Harbor, N.Y.

24. Hylemon, P. B., E. C. Gurley, R. T. Stravitz, J. S. Litz, W. M. Pandak, J. Y. L. Chiang, and Z. R. Vlahcevic. 1992. Hormonal regulation of cholesterol $7 \alpha$-hydroxylase mRNA levels and transcriptional activity in primary rat hepatocyte cultures. J. Biol. Chem. 267:16866-16871.

25. Jackson, D. A., K. E. Rowader, K. Stevens, C. Jiang, P. Milos, and K. Zaret. 1993. Modulation of liver-specific transcription by interactions between hepatocyte nuclear factor 3 and nuclear factor 1 binding DNA in close apposition. Mol. Cell. Biol. 13:2401-2410.

26. Jelinek, D. F., S. Andersson, C. A. Slaughter, and D. W. Russell. 
1990. Cloning and regulation of cholesterol $7 \alpha$-hydroxylase, the rate-limiting enzyme in bile acid biosynthesis. J. Biol. Chem. 265:8190-8197.

27. Jelinek, D. F., and D. W. Russell. 1990. Structure of the rat gene encoding cholesterol $7 \alpha$-hydroxylase. Biochemistry 29:7781-7785.

28. Karaoglu, D., and G. Gil. Unpublished data.

29. Kawasaki, E. S. 1990 . Sample preparation from blood, cells, and other fluids, p. 146-152. In M. A. Innis et al. (ed.), PCR protocols. A guide to methods and amplifications. Academic Press, Inc., San Diego, Calif.

30. Li, Y. C., D. P. Wang, and J. Y. L. Chiang. 1990. Regulation of cholesterol $7 \alpha$-hydroxylase in the liver. Cloning, sequencing, and regulation of cholesterol $7 \alpha$-hydroxylase mRNA. J. Biol. Chem. 265:12012-12019.

31. Liu, J.-K., C. M. DiPersio, and K. S. Zaret. 1991. Extracellular signals that regulate liver transcription factors during hepatic differentiation in vitro. Mol. Cell. Biol. 11:773-784.

32. Mitropoulos, K. A., and S. Balasubramaniam. 1976. The role of glucocorticoids in the regulation of the diurnal rhythm of hepatic $\beta$-hydroxy- $\beta$-methylglutaryl-coenzyme $A$ reductase and cholesterol 7 $\alpha$-hydroxylase. Biochem. J. 160:49-55.

33. Molowa, D. T., W. S. Chen, G. M. Cimis, and C. P. Tan. 1992. Transcriptional regulation of the human $7 \alpha$-hydroxylase gene. Biochemistry 31:2539-2544.

34. Monaci, P., A. Nicosia, and R. Cortese. 1988. Two different liver-specific factors stimulate in vitro transcription from the $\alpha 1$-antitrypsin promoter. EMBO J. 7:2075-2087.

35. Myant, N. B., and K. A. Mitropoulos. 1977. Cholesterol $7 \alpha$ hydroxylase. J. Lipid Res. 18:135-153.

36. Nitsch, D., M. Boshart, and G. Schutz. 1993. Activation of the tyrosine aminotransferase gene is dependent on synergy between liver-specific and hormone-responsive elements. Proc. Natl. Acad. Sci. USA 90:5479-5483.

37. Noshiro, M., M. Nishimoto, K.-I. Morohashi, and K. Okuda. 1989. Molecular cloning of cDNA for cholesterol $7 \alpha$-hydroxylase from rat liver microsomes. FEBS Lett. 257:97-100.

38. Noshiro, M., M. Nishimoto, and K. Okuda. 1990. Molecular cloning and sequence analysis of cDNA encoding human cholesterol $7 \alpha$-hydroxylase. FEBS Lett. 268:137-140.

39. Noshiro, M., M. Nishimoto, and K. Okuda. 1990. Rat liver $7 \alpha$-hydroxylase. Pretranslational regulation for circadian rhythm. J. Biol. Chem. 265:10036-10041.

40. Osborne, T. F. 1991. Single nucleotide resolution of sterol regulatory region in promoter for 3-hydroxy-3-methylglutaryl coenzyme A reductase. J. Biol. Chem. 266:13947-13951.

41. Palmiter, R. D., and R. L. Brinster. 1985. Transgenic mice. Cell 41:343-345.

42. Palmiter, R. D., and R. L. Brinster. 1986. Germ-line transformation of mice. Annu. Rev. Genet. 20:465-499.

43. Pinkert, C. A., D. M. Ornitz, R. L. Brinster, and R. D. Palmiter. 1987. An albumin enhancer located $10 \mathrm{~kb}$ upstream functions along with its promoter to direct efficient, liver-specific expression in transgenic mice. Genes Dev. 1:268-276.

44. Pondel, M. D., N. J. Proudfoot, and E. Whitelaw. 1992. The developmental regulation of the human $\zeta$-globin gene in transgenic mice employing $\beta$-galactosidase as a reporter gene. Nucleic Acids Res. 20:5655-5660.

45. Rosenthal, N. 1987. Identification of regulatory elements of cloned genes with functional assays. Methods Enzymol. 152:704-720.

46. Russell, D. W., and K. D. R. Setchell. 1992. Bile acid biosynthesis. Biochemistry 31:4737-4749.

47. Saiki, R. K., D. H. Gelfand, S. Stoffel, S. J. Scharf, R. Higuchi, G. T. Horn, K. B. Mullis, and H. A. Erlich. 1988. Primer-directed enzymatic amplification of DNA with a thermostable DNA polymerase. Science 239:487-491.

48. Sambrook, J., E. F. Fritsch, and T. Maniatis. 1989. Molecular cloning: a laboratory manual, 2nd ed. Cold Spring Harbor Laboratory, Cold Spring Harbor, N.Y.

49. Sanger, F., S. Nicklen, and A. R. Coulson. 1977. DNA sequencing with chain-terminating inhibitors. Proc. Natl. Acad. Sci. USA 76:5463-5467.

50. Shaul, Y., and R. Ben-Levy. 1987. Multiple nuclear proteins in liver cells are bound to hepatitis $\mathbf{B}$ virus enhancer element and its upstream sequences. EMBO J. 6:1913-1920.

51. Smith, J. R., T. F. Osborne, M. S. Brown, J. L. Goldstein, and G. Gil. 1988. Multiple sterol regulatory elements in promoter for hamster 3-hydroxy-3-methylglutaryl-coenzyme A synthase. J. Biol. Chem. 263:18480-18487.

52. Stravitz, R. T., P. B. Hylemon, D. M. Heuman, L. R. Hagey, C. D. Schteingart, H.-T. Ton-Nu, A. F. Hofmann, and Z. R. Vlahcevic. 1993. Transcriptional regulation of cholesterol $7 \alpha$-hydroxylase mRNA by conjugated bile acids in primary culture hepatocytes. J. Biol. Chem. 268:13987-13993.

53. Sundseth, S. S., and D. J. Waxman. 1990. Hepatic P-450 cholesterol $7 \alpha$-hydroxylase. Regulation in vivo at the protein and mRNA level in response to mevalonate, diurnal rhythm, and bile acid feedback. J. Biol. Chem. 265:15090-15095.

54. Swain, J. L., T. A. Stewart, and P. Leder. 1987. Parental legacy determines methylation and expression of an autosomal transgene: a molecular mechanism for parental imprinting. Cell 50: 719-727.

55. Twisk, J., E. M. Lehmann, and H. M. G. Princen. 1993. Differential feedback regulation of cholesterol $7 \alpha$-hydroxylase mRNA and transcriptional activity by rat bile acids in primary monolayer cultures of rat hepatocytes. Biochem. J. 290:685-691.

56. Zaret, K. S., C. M. Dipersio, D. A. Jackson, W. J. Montigny, and D. L. Weinstat. 1988. Conditional enhancement of liver-specific gene transcription. Proc. Natl. Acad. Sci. USA 85:9076-9080.

57. Zaret, K. S., J.-K. Liu, and M. Dipersio. 1990. Site-directed mutagenesis reveals a liver transcription factor essential for the albumin transcriptional enhancer. Proc. Natl. Acad. Sci. USA 87:5469-5473. 